\title{
Study of the Internal Morphology of the Mesiobuccal Root of Upper First Permanent Molar Using Cone Beam Computed Tomography
}

\author{
Estudio de la Morfología Interna de la Raíz Mesiovestibular del Primer Molar \\ Superior Permanente por Medio de Tomografía Computarizada Cone Beam
}

"Petronio de Albuquerque Campos Netto; **Carla Cabral dos Santos Accioly Lins; ${ }^{* * *}$ Carol Vasconcelos Lins; **** Georgina Agnelo Lima \& ${ }^{* * *}$ Marco Antônio Gomes Frazão

\begin{abstract}
CAMPOS NETTO, P. A.; LINS, C. C. S. A.; LINS, C. V.; LIMA, G. A. \& FRAZÃO, M. A. G. Study of the internal morphology of the mesiobuccal root of upper first permanent molar using cone beam computed tomography. Int. J. Morphol., 29(2):617-621, 2011.

SUMMARY: The aim of this study was to investigate and classify the internal morphology of the mesiobuccal root of upper first permanent molar, using the cone beam computed tomography. A total of 60 first permanent molars, not healthy and with intact pulp cavity, belonging to the Postgraduate dentistry bank, underwent the computed tomography. Axial images of each tooth were analyzed, and results showed that according to the number of conduits, 21 specimens (35\%) had single conduit and 39 exhibited two conduits (65\%). In reference to the types of internal configuration most commonly found according to Vertucci classification; type I (single channel that extends from the pulp chamber to the apex) was the most frequent (35\%), followed by type II (two separate canals leaving the pulp chamber and joining next to the apex forming a single channel) with 30\%. It was found that the morphology of the variation of mesiobuccal root, of upper first permanent molar is relatively high, and computed tomography proved to be an effective method for diagnosis.
\end{abstract}

KEY WORDS: Endodontics; Anatomy; Tomography.

\section{INTRODUCTION}

The knowledge of internal dental anatomy is fundamental to the achievement of endodontic treatment $(\mathrm{Ng}$ et al., 2001). Among the teeth, the upper first permanent molar is considered one which often, needs root canal treatment, thus special attention should be given to its pulp anatomy as it presents morphological variations, mainly in the mesiobuccal root (Smadi \& Khraisat, 2006).

Several techniques and methods have been used over the years to study the internal morphology among them: the injection of molten metal, liquid rubber, and resin inside the pulp cavity; method of tooth wear; serial histological sections; radiographic incidence, diafanization, and in recent years, computed tomography (Scarfe et al., 2006).

Among different computed tomography scans, the cone beam (TCCB), was designed specifically to evaluate hard tissues of the maxillofacial region (Rodrigues \& Vi- tral, 2007). It shows the following assets: precision of the images (real size and good definition), three-dimensional, affordable, and has a radiation dose equivalent to a radiographic periapical survey (Görduysus et al., 2001; Gopikrishna et al., 2008).

Thus, this study aimed to investigate and classify the internal morphology of the mesiobuccal root of upper first permanent molar, using cone beam computed tomography.

\section{MATERIAL AND METHOD}

A total of 60 upper first permanent molar, extracted, with complete rhizogenesis and chosen at random were used; 30 right and 30 left, obtained from the tooth bank of the Department of Prosthodontics and Oral-Facial Surgery, Fe-

* Dentist Specialist in Endodontics, Federal University of Pernambuco, Recife-PE, Brazil.

** PhD Professor of the Department of Anatomy, Federal University of Pernambuco, Recife-PE, Brazil.

**** Professor of the Department of Prosthodontics and Oral-Facial Surgery, Federal University of Pernambuco, Recife-PE, Brazil. 
deral University of Pernambuco, after approval by the Ethics Research Committee of Center of Health Sciences, Federal University of Pernambuco.

The specimens were immersed in sodium hypochlorite $1 \%$ for 48 hours, then washed in water for 20 minutes, and sterilized. They were divided into six layers of wax $\mathrm{N}^{\circ} 7$ (Horus) classified as A through $\mathrm{F}$, tied by orthodontic wire (Morest Standard Ø .010"). Each sheet of wax received ten teeth, which were positioned one beside the other, perpendicular the wax base. Then, they were listed 0-9.

Blocks $\mathrm{A}, \mathrm{B}$ and $\mathrm{C}$ received the right molars and blocks D, E and F left molars. Then the samples underwent cone beam computed tomography (CAT-i, model Next Generation Imaging Sciences, Hartfield, PA, USA) in volumetric acquisition with protocol $6 \mathrm{~cm}$ Field of View FOV, 40 seconds of $x$-ray exposure and voxel $0.12 \mathrm{~mm}$ in scale of 14-bit gray; the axial images were captured and analyzed on a computer i-CAT Vision software v1.6.2.
The images of the mesiobuccal root were analyzed by observing the number of channels and the types found; these were determined according to the classification of Vertucci (1984): type I: a single channel that extends from the pulp chamber to the apex; type II: two separate canals leaving the pulp chamber and joining near the apex forming a single channel; type III: a channel that leaves the pulp chamber, divides into two within the root, and unites again in a single channel; type IV: two separate and distinct canals extend from the pulp chamber to the apex; type V: a canal leaves the pulp chamber and divides into two near the apex, with distinct apical foramen, type VI: two separate channels leave the pulp chamber, unite the body of the root and redivide close to the apex, with distinct apical foramen; type VII: a channel leaves the pulp chamber, divides into two, unite in the body of the root and finally redivide on two channels near the apex; type VIII: three separate and distinct channels, extending from the pulp chamber to the apex (Fig. 1).
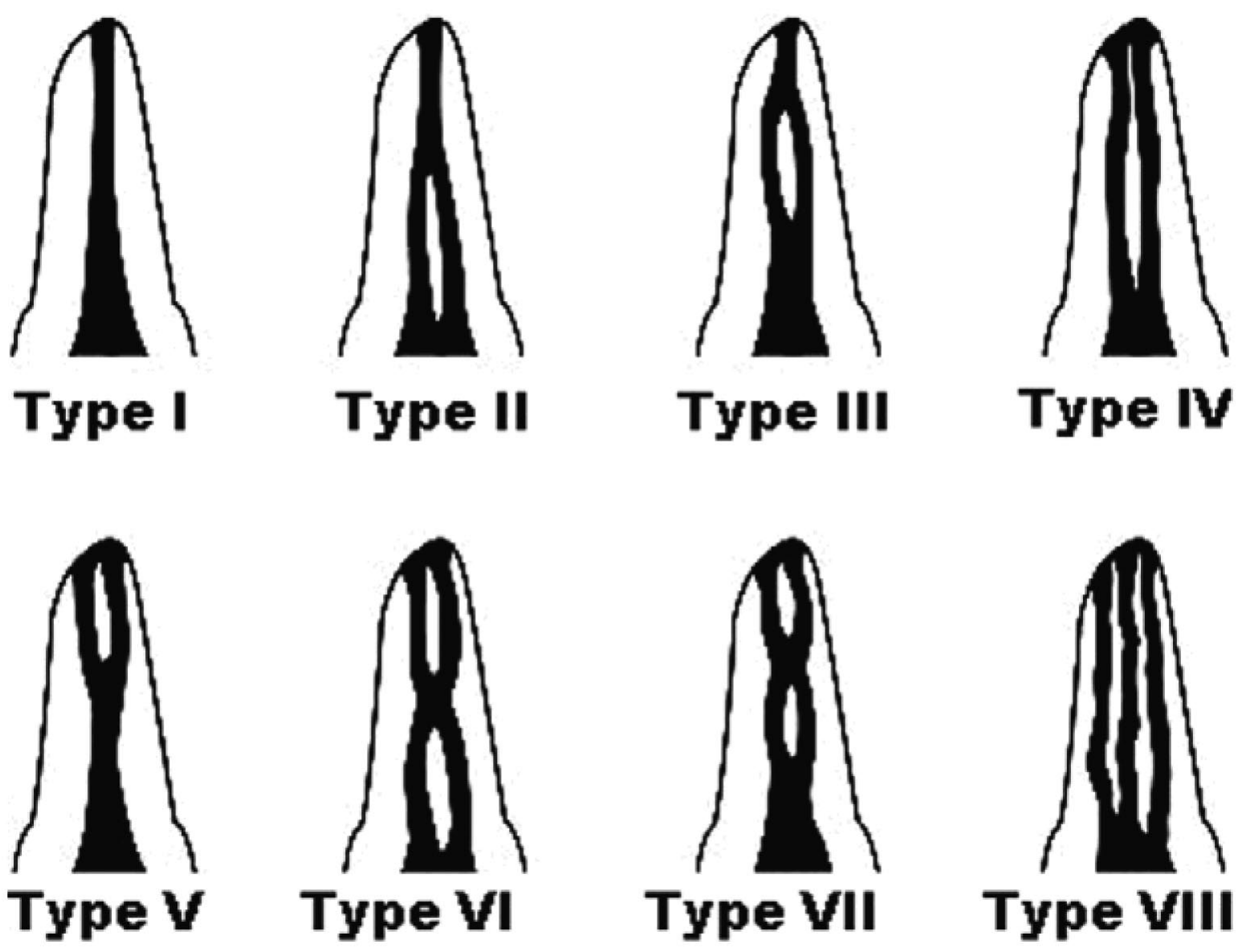
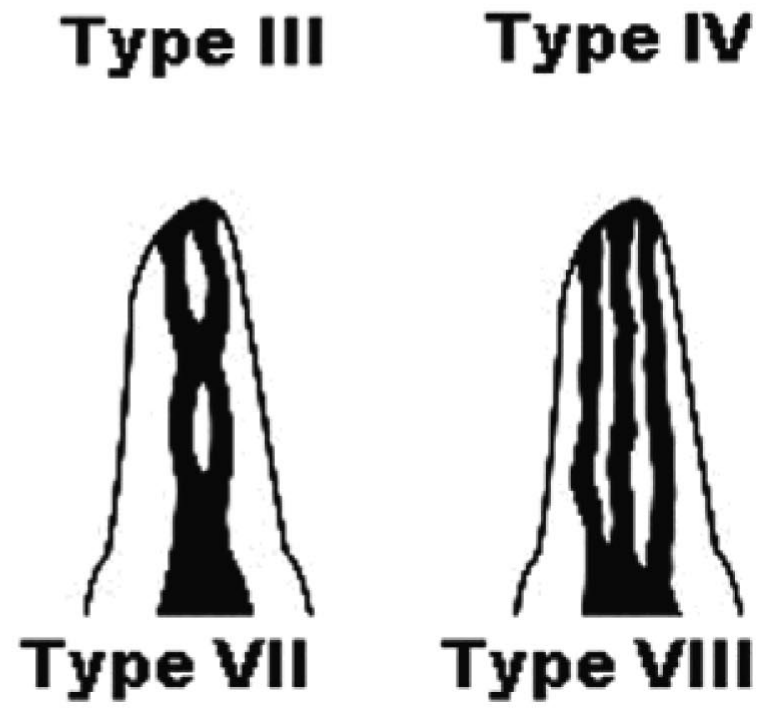

Fig. 1. Classification of root canal system according to Vertucci (1984). 


\section{RESULTS}

It was observed that according to the number of conduits, $35 \%$ of the specimen had a single conduit and $65 \%$ exhibited two conduits. Regarding the configuration of Vertucci, Type I was the most detected in $35 \%$ of specimens, followed by type II with $30 \%$, and type VIII was not found in any of the specimens (Table I).

In roots which had two ducts, type II was more commonly observed in $30 \%$ of specimens, followed by type IV, $6.66 \%$. The type V with $8.33 \%$, type III with $6.66 \%$, type VI with $3.33 \%$, type VII with $1.66 \%$ (Fig. 2).

Table I. Analysis of specimens according to the classification of Vertucci (1984).

\begin{tabular}{ccc}
\hline Canal type & $\mathrm{N}^{\circ}$ Specimen & $\%$ \\
\hline I & 21 & 35.0 \\
II & 18 & 30.0 \\
III & 4 & 6.6 \\
IV & 9 & 15.0 \\
V & 5 & 8.3 \\
VI & 2 & 3.3 \\
VII & 2 & 1.6 \\
VIII & 0 & 0.0 \\
\hline Total & 60 & 100 \\
\hline
\end{tabular}

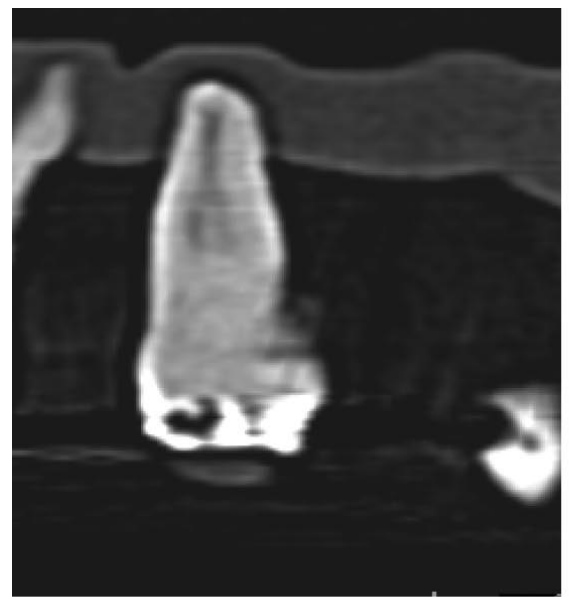

Type II

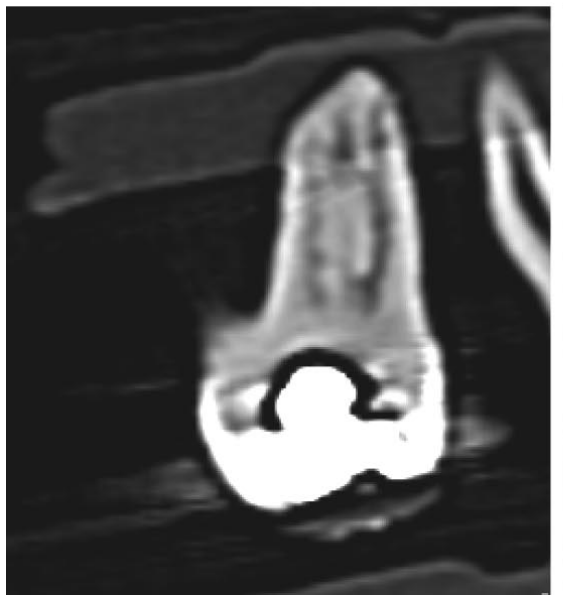

Type V

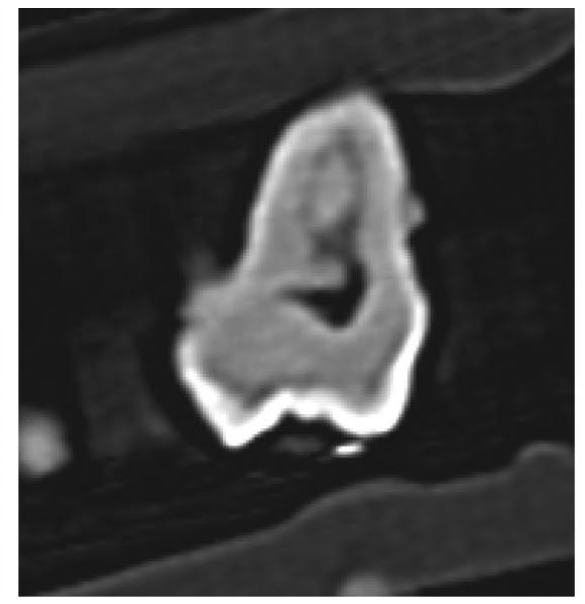

Type III

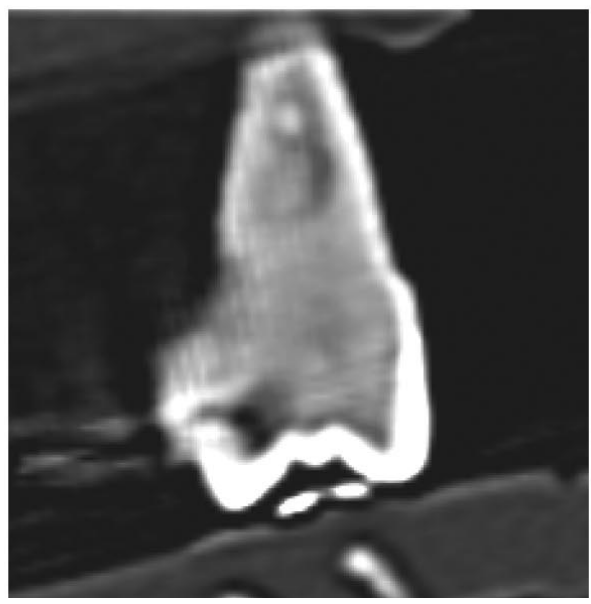

Type VI

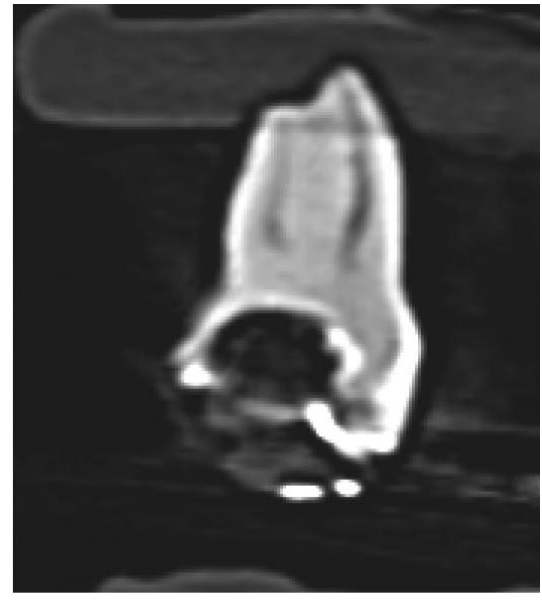

Type IV
Fig. 2. Computed tomographic image showing the configuration of the root canal el according to the division of Vertucci (1984).

\section{DISCUSSION}

The interest in studying the internal morphology of the mesiobuccal root of upper first permanent molar was started in 1925, when Hess reported the presence of two conduits. Since then studies have not stopped, and endodontic 
therapy has improved with new techniques and equipment, seeking to facilitate knowledge of anatomical variations for the proper treatment of the teeth (Ferreira et al., 2007).

The technique of cone beam computed tomography (TCCB), used in our study favors the detection of anatomical details with more accuracy when compared to other techniques because it allows a three-dimensional view of the dental element facilitating the recognition of the number of channels (Garib et al., 2002; Silva et al., 2003), as well as the ability to acquire a large number of sections of images in both the sagittal, coronal and axial axis (Pécora et al., 1992; Silva et al.; Hatcher \& Aboudara, 2004).

The morphological variation found in our study corroborates the observations of other researchers who also found a prevalence of 2 conduits on a single conduit (Vertucci; Kulid \& Peters, 1990; De Deus, 1992; Weine et al., 1999; Sydney et al., 2000; Silveira et al., 2005; Baratto Filho et al., 2009).
In the images of the channel systems of the mesiobuccal root with two conduits, the pattern was type II (30\%), followed by type IV $(15 \%)$. These data collaborate with other researchers, who reported in their studies a predominance of type II (42\%) (Noga \& Moro, 2007), but followed by type III (Görduysus et al.; Tam \& Yu, 2002). It was observed that presence of the second channel increased, when used in a laboratory mean of expansion TTCB facilitating diagnosis (Cleghorn et al., 2006; Somma et al., 2008; Baratto Filho et al.).

\section{CONCLUSION}

After the obtained results, we concluded that the upper first permanent molar has two ducts in mesiobuccal root at a rate higher than the occurrence of only one conduit, and that the cone beam computed tomography is an auxiliary method in the diagnosis of anatomical variations, helping the endodontics expert to conduct clinical treatment successfully.

CAMPOS NETTO, P. A.; LINS, C. C. S. A.; LINS, C. V.; LIMA, G. A. \& FRAZÃO, M. A. G. Estudio de la morfología interna de la raíz mesiovestibular del primer molar superior permanente por medio de tomografía computarizada cone beam. Int. J. Morphol., 29(2):617-621, 2011.

RESUMEN: El objetivo de este estudio fue investigar y clasificar la morfología interna de la raíz mesiovestibular del primer molar permanente superior, utilizando la tomografía computarizada cone beam. Fueron utilizados 60 primeros molares permanentes superiores, pertenecientes al Banco de Dientes del Posgrado en Odontología, con cavidad pulpar intacta, los cuales fueron sometidos a TC. Se analizaron las imágenes axiales de cada diente y se obtuvieron los siguientes resultados: 21 muestras (35\%) tenían un solo canal y 39 muestras (65\%) dos canales; los tipos de configuración interna más comunes de acuerdo a la clasificación Vertucci fueron: Tipo I, $35 \%$, un solo canal que se extiende desde la cámara pulpar hasta el ápice radicular y Tipo II, 30\% dos canales separados que salen de la cámara pulpar y se unen cerca del ápice radicular formando un solo canal. La morfología de la raíz mesiovestibular del primer molar superior era relativamente alta. La tomografía computarizada demostró ser un método eficaz para el diagnóstico.

PALABRAS CLAVE: Endodoncia; Anatomía; Tomografía.

\section{REFERENCES}

Baratto Filho, F.; Zaitter, S.; Haragushiku, G. A.; de Campos, E. A.; Abuabara, A. \& Correr, G. M. Analysis of the internal anatomy of maxillary first molars by using different methods. J. Endod., 35(3):337-42, 2009.

Cleghorn, B. M.; Christie, W. H. \& Dong, C. C. Root and root canal morphology of the human permanent maxillary first molar: a literature review. J. Endod., 32(9):813-21, 2006.

De Deus, Q. D. Endodontia. $5^{\mathrm{a}}$ ed. Rio de Janeiro, MEDSI, 1992. pp.695.
Ferreira, P. O. M.; Ferreira, E. L.; Fariniuk, L. F.; Baratto, F.; Haragushiku, G. A. \& Sayão, S. M. A. Análise radiográfica da trajetória do quarto canal no primeiro molar superior. Rev. Sul-Bras. Odontol,4(2):52-8, 2007.

Garib, D. B.; Raymundo Júnior, R.; Raymundo, M. V.; Raymundo, D. V. \& Ferreira, S. N. Tomografia computadorizada de feixe cônico (Cone Beam): Entendendo este novo método de diagnóstico por imagem com promissora aplicabilidade na ortodontia. R. Dent. Press Ortodon. Ortop. Facial, 12(2):139-56, 2002. 
Gopikrishna, V.; Reuben, J. \& Kandaswamy, D. Endodontic management of a maxillary first molar with two palatal roots and a single fused buccal root diagnosed with spiral computed tomography - a case report. Oral Surg. Oral Med. Oral Pathol. Oral Radiol. Endod., 105(4):74-8, 2008.

Görduysus, M. Ö.; Görduysus, M. \& Friedman, S. Operating microscope improves negotiation of second mesiobuccal canals in maxillary molars. J. Endod., 27(11):683-6, 2001.

Hatcher, D. C. \& Aboudara, C. L. Diagnosis goes digital. Am. J. Orthod. Dentofacial Orthop., 125(4):512-5, 2004.

Kulid, J. C. \& Peters, D. D. Incidence and configuration of canals systems in the mesiobuccal root of maxillary first and second molars. J. Endod., 16(7):311-7, 1990.

Ng, Y. L.; Aung, T. H.; Alavi, A. \& Gulabivala, K. Root and canal morphology of Burmese maxillary molars. Int. Endod. J., 34(8):620-30, 2001.

Noga, K. \& Moro, A. Tomografia computadorizada de feixe cônico (cone beam) na odontologia. Revista Dens, 15(2):30-4, 2007.

Pécora, J. D.; Woelfel, J. B.; Sousa Neto, M. D. \& Issa, E. P. Morphologic study of the maxillary molars - Part II: internal anatomy. Braz. Dent. J., 3(1):53-7, 1992.

Rodrigues, A. F. \& Vitral, R.W. Aplicações da Tomografia Computadorizada na Odontologia. Pesq. Bras. Odontoped. Clin. Integr., 7(3):317-24, 2007.

Scarfe, W. C.; Farman, A. G. \& Sukovic, P. Clinical applications of cone-beam computed tomography in dental practice. J. Can. Dent. Assoc., 72(1):75-80, 2006.

Silva, P. S. F.; Silveira, F. S. C. \& Soares, M. R. Anatomia da raiz mesio-vestibular de primeiros molares superiores-Diafanização. J. Brás. Endod., 4(14):199-202, 2003.

Silveira, L. F. M.; Danesib, V. C. \& Baischc, G. S. Estudo das relações anatômicas entre os canais mesiais de molares inferiores. Revista de Endodontia Pesquisa e Ensino On Line, 1(2):16-21, 2005.

Smadi, L. \& Khraisat, A. Root canal morphology of the mesiobuccal root of the maxillary first molar. Gen. Dent., 54(6):413-6, 2006.
Somma, F.; Leoni, D.; Plotino, D.; Grande, N. M. \& Plasschaert, A. Root canal morphology of the mesiobuccal root of maxillary first molars: a microcomputed tomographic analysis. Int. Endod. J., 42:16574, 2008.

Sydney, R. B.; Sydney, G. B. \& Batista, A. Análise clínica e radiográfica da frequiência de um quarto canal na raiz mesiovestibular dos molares superiores. Rev. Odontol. Univ. Ribeirão Preto, 3(2):67-74, 2000.

Tam, A. \& Yu, D. C. Location of canal isthmus and accessory canals in the mesiobuccal root of maxillary first permanent molars. J. Can. Dent. Assoc., 68(1):28-33, 2002.

Vertucci, F. J. Root canal anatomy of the human permanent teeth. Oral Surg. Oral Med. Oral Pathol., 58(5):58999, 1984.

Weine, F. S.; Hayami, S.; Hata, G. \& Toda, T. Canal configuration of the mesiobuccal root of the maxillary first molar of a Japanese sub-population. Int. Endod. J., 32(2):79-87, 1999.

Correpondence to:

Prof. Carla Cabral dos Santos Accioly Lins

Department of Anatomy

Universidade Federal de Pernambuco

Rua Manuel de Carvalho, $n^{\circ} 310$, apt 303, aflitos

CEP 52050-370, Recife- PE

BRASIL

Email: cabralcarla1@hotmail.com

Received: 14-01-2011

Accepted: 24-02-2011 